\title{
How Nucleophillic Are Silyl Enol Ethers? \\ Kinetics of the Reactions of Electron Rich CC-Double Bonded Systems with Carbenium Ions
}

\author{
Matthias Patz and Herbert Mayr
}

Institut für Organische Chemie, Technische Hochschule Darmstadt, Petersenstr. 22, W-6100 Darmstadt, Fedenl Republic of Germany

\begin{abstract}
Rate constants for the reactions of the bis(p-dimethylaminophenyl)carbenium ion 1 with silyl enol ethers, allyl silanes, and allyl stannanes show the reactivity order $\mathrm{H}_{2} \mathrm{C}=\mathrm{CR}-\mathrm{CH}_{2} \mathrm{SiMe}_{3}<\mathrm{H}_{2} \mathrm{CaCR}-\mathrm{OSiMe}_{3}<$ $\mathrm{H}_{2} \mathrm{C}=\mathrm{CR}-\mathrm{CH}_{2} \mathrm{SnBu}_{3}$.
\end{abstract}

In spite of the enormous importance, reactions of cationic electrophiles with silylated enol ethers have adopted in organic synthesis, 1 kinetic data on such reactions are rare.,3 ${ }^{2,3}$ Previously we have reported rate constants for the reactions of alkenes, allylelement compounds, and enol ethers toward chloro-, methyl-, and alkoxy-substituted benzhydryl cations.3,4 Because of the high nucleophilicity of alkyl and silyl enol ethers, the rate constants of their reactions with these carbocations are very high, often approaching the diffusion limit.

In order to obtain insight into the relationship between structure and nucleophilicity of silyl enol ethers, we have now investigated their reactivities toward the considerably less electrophilic bis(pdimethylaminophenyl)carbenium ion 1 . In addition, we report some rate constants for the reactions of this carbenium ion with allylsilanes and allylstannanes, which provide a connection to the reactivity scale of $\pi$ nucleophiles, previously reported. 5

The kinetic experiments have generally been carried out with the bis(p-dimethylaminophenyl)carbenium triflate(1-OTF), prepared by reaction of the corresponding alcohol with 1 equivalent of trifluoromethanesulfonic acid in dry THF at $20^{\circ} \mathrm{C}$. In accord with the reaction mechanism described in Scheme 1, the photometrically monitored reactions follow second order kinetics, as previously reported for analogous reactions of other benzhydryl cations. 4,5
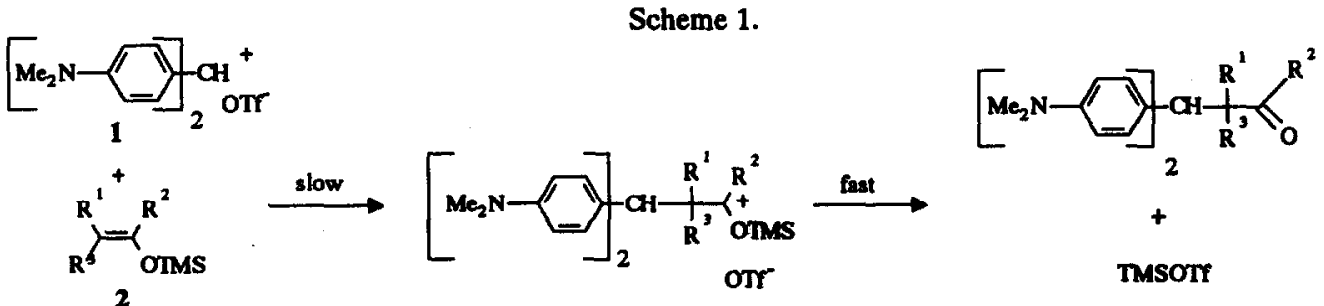

For the reaction of 1 with $2 c$, the influence of the counterion has been investigated. Within experimental error, 1-OTf $\left[k_{2}\left(20^{\circ} \mathrm{C}\right)=0.361 \mathrm{~L} \mathrm{~mol}^{-1} \mathrm{~s}^{-1}\right]$ and $1-\mathrm{Cl}^{-}\left(0.368 \mathrm{~L} \mathrm{~mol}^{-1} \mathrm{~s}^{-1}\right)$ showed the same reactivity, as previously observed for related reactions. ${ }^{4 a, d}$ 
Table 1. Rate Constants for the Reactions of the Bis(p-dimethylaminophenyl)carbenium Ion 1 with Silylated Enol Ethers and other Electron-Rich $\pi$-Systems $\left(20^{\circ} \mathrm{C}, \mathrm{CH}_{2} \mathrm{Cl}_{2}\right)$

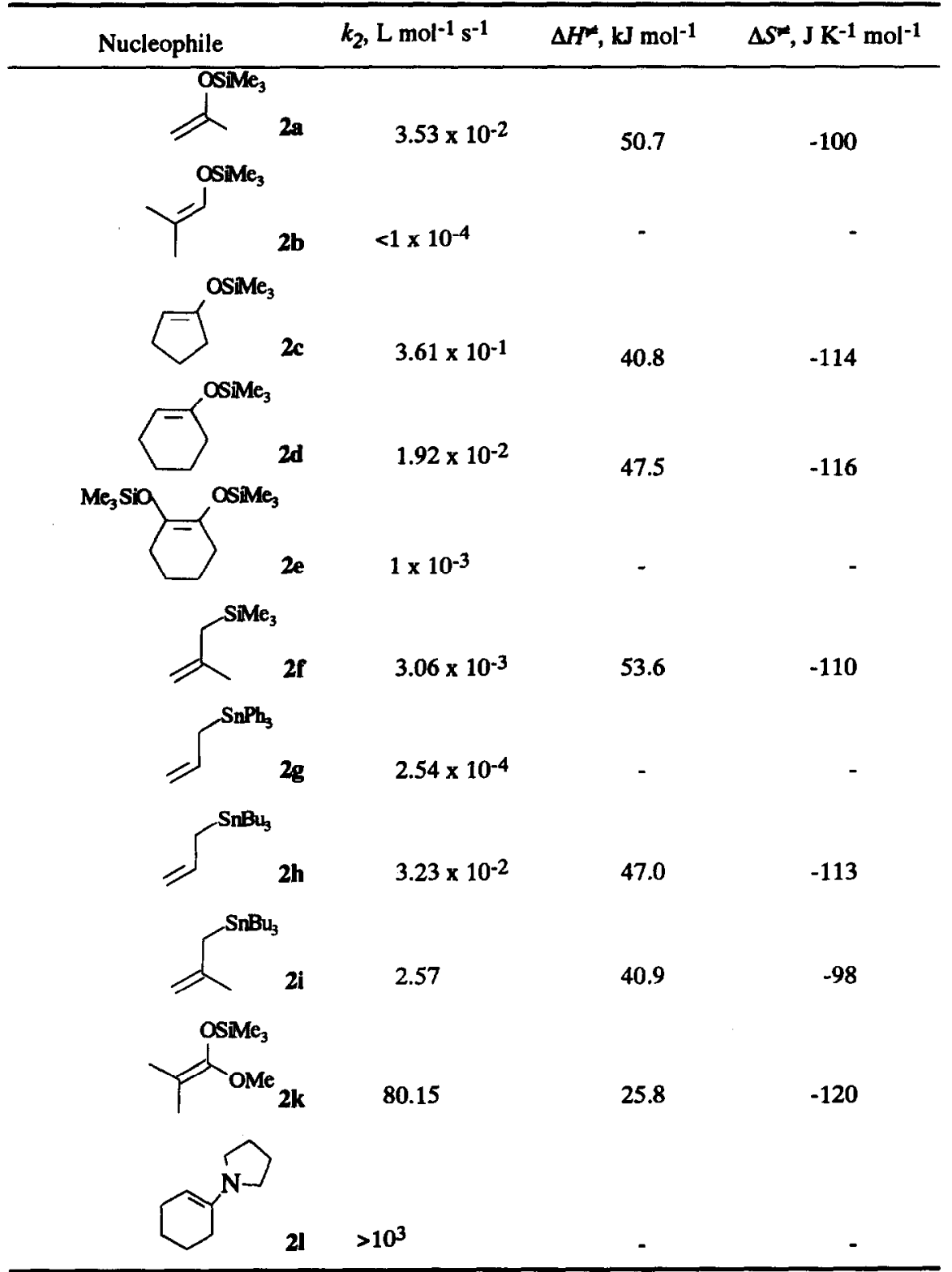

The data in Scheme 2 allow a direct comparison of the reactivities of structurally related allylsilanes, silyl enol ethers, and allylstannanes (activating effects $\mathrm{CH}_{2} \mathrm{SiMe}_{3}<\mathrm{OSiMe}_{3}<\mathrm{CH}_{2} \mathrm{SnBu}_{3}$ ). Since silyl enol ethers and alkyl enol ethers differ only slightly in reactivity, ${ }^{3}$ this order indicates that the hyperconjugative effect of the $\mathrm{CH}_{2}-\mathrm{SnBu}_{3}$ group is significantly larger than the conjugative effect of the OR group. 
Scheme 2.

$k_{\text {rel }}$<smiles>C=C(C)C[AsH3]</smiles>

1.0<smiles>C=C(C)O[Si](C)(C)C(=O)O[Si](C)(C)C</smiles>

12<smiles>C=C(C)C[SbH2]</smiles>

840

In analogy to the reactivity order of the corresponding hydrocarbons (isobutene $=1$-methylcyclohexene $<$ 1-methylcyclopentene), $4 \mathrm{~b}$ compound $2 \mathrm{~d}$ and the acyclic enol ether $2 \mathrm{a}$ show comparable nucleophilicities, while the analogous cyclopentene derivative $2 c$ is considerably more reactive (Scheme 3). A similar reactivity ratio has been reported for the reactions of compounds $2 c$ and $2 d$ with nitrosoalkenes. 6

Scheme 3.<smiles>[R]C(=C)C</smiles><smiles>[R]C1=CCCCC1</smiles><smiles>[R]C1=CCCC1</smiles>

$\mathbf{R}=\mathrm{CH}_{3}$ 1

0.37 22

$\mathrm{R}=\mathrm{OSiMe}_{3}: \quad k_{\text {rel }}\left(1,+20^{\circ} \mathrm{C}\right)$ 1

0.54

10

The 1,2-bis(trimethylsiloxy)-substituted cyclohexene $2 e$ is one order of magnitude less reactive than the analogous monosubstituted compound 2d. Analogously, 1,2-dialkoxyethylenes have been reported to be protonated slower than monoalkoxyethylenes. ${ }^{7}$

The comparison between the silyl enol ether $\mathbf{2 b}$ and the structurally related ketene acetal $2 \mathbf{k}$ indicates an acceleration of more than a factor of $10^{5}$ by the additional methoxy group. Compound 21 , the only enamine studied up to now, is so reactive that its reaction with 1 could not even be measured at $-60^{\circ} \mathrm{C}$, i.e., the nucleophilicity of enamines exeeds that of silylated ketene acetals by several orders of magnitude.

Table 2. Rate Constants $\left(k_{2}, \mathrm{~L} \mathrm{~mol}^{-1} \mathrm{~s}^{-1}\right)$ for the Reactions of Different Benzhydryl Cations with Reactive Vinyl Derivatives $\left(20^{\circ} \mathrm{C}\right)$

\begin{tabular}{|c|c|c|c|c|c|c|}
\hline$X=L$ & 1 & $b_{3}$ & & $\mathrm{OSiMe}_{3}$ & & OST \\
\hline \multirow[t]{2}{*}{$\mathrm{NMe}_{2}$} & $k_{2}$ & $2.54 \times 10^{-4}$ & $3.04 \times 10^{-3}$ & $1.91 \times 10^{-2}$ & $3.21 \times 10^{-2}$ & $3.61 \times 10^{-1}$ \\
\hline & $k_{\text {rel }}$ & 1 & 12 & 75 & 126 & 1420 \\
\hline \multirow[t]{2}{*}{ OMe } & $k_{2}$ & $9.3 \times 10^{2 b)}$ & $\left.1.4 \times 10^{4} b\right)$ & ca.1.7 $\times 10^{5}$ ) & $\left.6.9 \times 10^{4} b\right)$ & - \\
\hline & $k_{\text {rel }}$ & 1 & 15 & ca.180 & 74 & - \\
\hline \multirow[t]{2}{*}{$\mathbf{M e}$} & $k_{2}$ & $1.9 \times 10^{69)}$ & - & $1.3 \times 10^{8 \mathrm{e})}$ & - & $6.0 \times 10^{8 e)}$ \\
\hline & $k_{\text {rel }}$ & 1 & - & 68 & - & 316 \\
\hline \multirow[t]{2}{*}{$\mathrm{Cl}$} & $\left.k_{2}^{e}\right)$ & - & $6.7 \times 10^{8}$ & $2.3 \times 10^{9}$ & - & $2.5 \times 10^{9}$ \\
\hline & $k_{\text {rel }}$ & - & 1 & 3.4 & - & 3.7 \\
\hline
\end{tabular}

a) Extrapolated from linear free energy relationships from $k_{2}\left(-70^{\circ} \mathrm{C}^{4 \mathrm{~d}}\right.$ assuming an activation eatropy of $-110 \mathrm{~J} \mathrm{maj}^{-1} \mathrm{~K}^{-1}$; b) Extrapolated from $k_{2}\left(-70^{\circ} \mathrm{C}\right)^{40}$ assuming an activation entropy of $\left.-110 \mathrm{~J} \mathrm{~mol} \mathrm{l}^{-1} \mathrm{~K}^{-1} ; \mathrm{c}\right)$ Extmpolated from $k_{2}\left(-70^{\circ} \mathrm{C}\right)^{8}$ assuming an activation entropy of $-116 \mathrm{~J} \mathrm{~mol}^{-1} \mathrm{~K}^{-1}$; e) Ref. [3]

Table 2 shows that the selectivities of the bis(p-dimethylamino)- and the bis(p-methoxy)diphenylcarbenium ion are closely similar, in spite of dramatically different absolute rate constants. This constancy is not expected for all nucleophiles, since in activation controlled reactions of this type, selectivities may increase. decrease or remain constant as the reactivity of the carbenium ion increases. 499 The domain of 
the reactivity selectivity principle, i.e., decreasing selectivity with increasing reactivity, is encountered, however, when reactions with rate constants close to the diffusion limit are considered (see lower two entries of Table 2).

The reactions do not proceed via SET processes. In recent work Fukuzumi and Otera ${ }^{10}$ investigated the rates of electron transfer from $2 d$ and $2 k$ to various one-electron oxidants. On the basis of this work, one can derive rate constants for the electron transfer reaction from $2 \mathrm{~d}\left(1 \times 10^{-18} \mathrm{~L} \mathrm{~mol}^{-1} \mathrm{~s}^{-1}\right)$ and $2 \mathrm{k}\left(1 \times 10^{-12} \mathrm{~L} \mathrm{~mol}^{-1} \mathrm{~s}^{-1}\right)$ to the carbenium jon 1 , for which $E_{1 / 2}=-0.4 \mathrm{~V}$ vs SCE has been assumed ${ }^{11}$. As the numbers are considerably smaller than the observed rate constants (Table 1), the reactions investigated in this work must occur via polar mechanisms.

The reactivity order of silyl enol ethers reported in Table 1 is in qualitative agreement with that previously derived from LASER flash photolytic measurements with more reactive carbenium ions. ${ }^{3}$ Since $\boldsymbol{k}_{2}$ values determined in this work are far from diffusion control, the "true" structure reactivity relationships now become evident, and silylated enol ethers can be added to the nucleophilicity scale previously developed for alkenes, allyl element compounds, and arenes. 5,12

Acknowledgment: We thank the Fonds der Chemischen Industrie (Kekule grant to M.P.) and the Deutsche Forschungsgemeinschaft for financial support .

\section{References and Notes}

1. (a) Reetz, M.T. Angew. Chem. 1982, 94, 97; Angew. Chem., Int. Ed. Engl. 1982, 21, 96. (b) Mukaiyama, T.; Murakami, M. Synthesis 1987, 1043. (c) Povarov, L.S. Russ. Chem. Rev. (Engl. Transl.) 1985, 34, 639. (d) Paterson, 1. Tetrahedron 1988, 44, 4207. (e) Brownbridge, P. Synthesis, 1983, 1, 85. (f) Caine, D. in Comprehensive Organic Synthesis; Trost, B. M.; Fleming, I.; Pattenden G., Eds. ; Pergamon Press: Oxford, 1991; Vol. 3 pp. 25.

2. Novice, M.H.; Seikaly, H.R.; Seiz, A.D.; Tidwell, T.T. J. Am. Chem. Soc. 1980, 102, 5835.

3. Bartl, J.; Steenken, S.; Mayr, H. J. Am. Chem. Soc. 1991, 113, 7710.

4. (a) Mayr, H.; Schneider, R.; Schade, C.; Bartl, J.; Bederke, R. J. Am. Chem. Soc. 1990, 112, 4446. (b) Mayr, H.; Schneider, R.; Irrgang, B.; Schade, C. J. Am. Chem. Soc. 1990, 112, 4454. (c) Mayr, H.; Schneider, R.; Grabis, U. J. Am. Chem. Soc. 1990, 112, 4460. (d) Hagen, G.; Mayr, H. J. Am. Chem. Soc. 1991, 113, 4954. (e) Review: Mayr, H. Angew. Chem. 1990, 102, 1415; Angew. Chem. Int. Ed. Engl. $1990,29,1371$.

5. Mayr, H.; Bartl, J.; Hagen, G. Angew. Chem. 1992, 104, 1689; Angew. Chem., Int. Ed. Engl. 1992, 31, 1613.

6. ReiBig, H.-U.; Hippeli, C.; Amold, T. Chem. Ber. 1990, 123, 2403.

7. (a) Knittel, P.; Tidwell, T.T. J. Am. Chem. Soc. 1977, 99, 3408. (b) Kresge, A.J.; Leibovitch, M. J. Org. Chem. 1990, 55, 5234. (c) Kresge, A.J.; Leibovitch, M. J. Am. Chem. Soc. 1992, 114, 3099.

8. Mayr, H.; Patz, M. unpublished results.

9. Mayr, H.; Schneider, R.; Grabis, U. Angew. Chem. 1986, 98, 1034; Angew. Chem., Int. Ed. Engl. 1986, 25, 1017.

10. Fukuzumi, S.; Fujita, M.; Otera, J.; Fujita, Y.J. Am. Chem. Soc. 1992, 114, 10271.

11. The oxidation potential of the cation 1 is estimated using the correlation between $p K_{R^{+}}$and $E_{1 / 2}$ (Sim, B.A; Milne, P.H.; Griller, D.; Wayner, D.D.M. J. Am. Chem. Soc. 1990, 112, 6635) and $p K_{R}+(1)=5.61$ (Goldacre, R.J.; Philips, J.N. J. Chem.Soc. 1949, 1724).

12. Fleming, I. Chemtracts-Organic Chemistry 1992, 5, 8.

(Received in Germany 12 March 1993) 